\title{
Comparison between the Effect of Sublingual and Rectal Misoprostol on Hemoglobin Level Change before and after Caesarean Section
}

\author{
Mohamed Abd-Elghafar Sayed, Sayed Mohamed Sayed and, Marwa Mohamed Ibrahim \\ Obstetrics and Gynecology department, Faculty of Medicine, Beni-Suef University, Egypt
}

\begin{abstract}
Cesarean delivery is the commonest women surgery worldwide. Postpartum hemorrhage is blood loss $>1000 \mathrm{ml}$ after SC. This study conducted to assess the efficacy of sublingual versus rectal misoprostol on intraoperative and postoperative blood loss and the subsequent effect on hemoglobin values. This was a prospective study that included 100 pregnant women divided randomly into two equal groups, 50 participants each admitted to the department of obstetrics and gynecology, BeniSuef university hospital- Egypt from August 2018 to May 2019. Participants received 400 mcg rectally or sublingually before SC after induction of spinal anesthesia. The primary outcome measure perioperative hemoglobin and hematocrit values regarding blood loss. Comparisons between groups were carried out by Student's t-test (parametric data), Mann Whitney test (Nonparametric data), and Chi-Square test. $P<0.05$ was considered statistically significant
\end{abstract}

Keywords: Caesarean delivery, Misoprostol, Postpartum hemorrhage.

\section{Introduction}

Cesarean delivery is the commonest major women's surgery worldwide [1]. The incidence ranges from $20-30 \%$ all over the world [2]. Postpartum hemorrhage defined as loss of $>1,000 \mathrm{ml}$ after cesarean delivery (uterine atony cause about $75 \%$ ) [3], with incidence range from 5-10\% [4]. Postpartum hemorrhage is a major cause of maternal mortality, mainly in developing countries and is the cause of about
$25 \%$ of maternal deaths worldwide [5]. Using traditional uterotonics is accepted in the prevention of PPH after cesarean delivery [6]. Misoprostol [PGE1]) is one of the synthetic PGE1 analogs with strong uterotonic activity and few side effects at therapeutic doses [7]. Misoprostol is safe, stable, rapidly absorbed, easy to be used (oral, vaginal, buccal, or rectal), of low cost, and its effect on the uterus [8]. 
Misoprostol has been considered an alternative to injectable uterotonic agents for the prevention of $\mathrm{PPH}$ after vaginal or cesarean deliveries [9]. Sublingual misoprostol reaches the highest peak plasma concentration within the shortest time [6], with no adverse neonatal effects after the preoperative use of sublingual misoprostol in cesarean delivery [10].

\section{Patients and Methods}

This was a prospective study performed in in Beni-Suef university hospital and Maghagha General hospital within Nine months from August 2018 to May 2019 involving 100 pregnant women divided randomly into two equal groups Participants have undergone a CS under spinal anesthesia. Group (I): Sublingual misoprostol: cases administrated preoperatively $400 \mathrm{mcg}$ misoprostol sublingually at the time of induction of spinal anesthesia. Group (II): Rectal misoprostol: cases administrated preoperatively $400 \mathrm{mcg}$ misoprostol rectally after insertion of the urinary catheter. Written consents were obtained.

\subsection{Inclusion criteria:}

1. Age from 18 to 35 years.

2. Uncomplicated singleton pregnancy.

3. Term pregnancy of gestational age $(37: 40$ wks.).

4. Elective or an emergency section.

5. Parity $\leq 4$.

6. $\mathrm{Hb} \geq 9 \mathrm{~g} / \mathrm{dl}$.
7. Previous $\mathrm{CSs} \leq 2$.

\section{Exclusion criteria:}

1. Known history of the medical disease (hypertension, cardiac, pulmonary, chronic endocrine or metabolic disease).

2. Risk factor for postpartum hemorrhage.

3. Contraindication to prostaglandins (severe asthma, hypersensitivity to the drug).

4. Placenta previa or abruption.

5. Blood diseases affecting coagulation profile.

2.2 All patients were subjected to the following:

1. Full history taking: Personal history, history of chronic medical disorders, obstetric history.

\section{Clinical examination including:}

A. General, local and physical examination, and measurements (weight, respiration rate, and heart rate, and routine obstetric examination).

B. Obstetric ultrasonography was performed for all patients to make sure of gestational age using (TOSHIBA SSA-340A diagnostic ultrasound).

\section{Laboratory investigations:}

A volume of $3 \mathrm{ml}$ blood sample was collected under the fully sterile condition from all cases in a tube containing EDTA for assessment of CBC. Blood samples were collected from all patients before \& 24 hours after the CS. CBC determined by using automated cell counter Sysmex, NE (TAO, Medical Incorporation, Ono) stressing on hemoglobin $(\mathrm{Hb})$ and packed cell volume or Heamatocrit (Hct). 
The outcomes measured were the change of Hct and $\mathrm{Hb}$ values, the estimation of the intraoperative blood loss, the incidence of severe PPH $(>1000 \mathrm{ml})$, the need for blood transfusion and the need for further uterotonics. The surgical towels were weighed $(\mathrm{g})$ with its wrapping before and after the operation via using a highly accurate digital balance (National, Xiamen Yukexiang Trading Co., Ltd.) and the differences in weight between dry and soaked linen towels were calculated. Blood loss was estimated accordingly: volume of the contents of the suction bottle $(\mathrm{ml})(\mathrm{A})$, the weight difference of linen towels (g) (B) [weight of soaked linen towels $(\mathrm{g})$ - weight of dry linen towels (g)], AFV (ml) (C). Thus, blood loss during operation $(\mathrm{ml})=(\mathrm{A}+\mathrm{B})-\mathrm{C}$ [11].

\subsection{Sample size determination}

Sample size calculation was done using the comparison of $\mathrm{Hb}$ deficit between cases undergoing Cesarean section pretreated with sublingual versus rectal misoprostol as it was the primary outcome of our study. we calculated that the minimum proper sample size was 17 cases in each arm to achieve $80 \%$ power in detecting a difference of $0.6 \mathrm{~g} / \mathrm{dl}$ with a pooled SD of $0.65 \mathrm{~g} / \mathrm{dl}$, at $\alpha=0.05$ level using Student's T-test for independent samples. Sample size calculation was done using Stats Direct statistical software version 2.7.2 for MS Windows, Stats Direct Ltd., Cheshire, UK.

\section{Statistical methodology}

All statistical analyses were performed using Statistical Package for Social Science (SPSS) version 21 under Windows 7 operating system. Results were expressed as means \pm SD for quantitative data and by No. (\%) for qualitative data. Comparisons between the groups were conducted by Student's t-test for parametric data and by Mann Whitney test for Nonparametric data. Chi-Square test was used to test the significance between groups regarding qualitative data or Fisher exact test when appropriate. Probability level (P-value) was assumed significant if less than 0.05 and highly significant if P-value was less than 0.01. P-value was considered non-significant if greater than or equal to 0.05 .

\section{Results}

The present study included a total of 100 pregnant women with an age range of 18:35 years that were randomly divided into two equal groups: Group (I): Sublingual misoprostol $(\mathrm{n}=50)$ : Women administrated preoperatively with misoprostol sublingually at the time of induction of spinal anesthesia. Group (II): Rectal misoprostol $(n=50)$ : Women administrated preoperatively with misoprostol rectally after insertion of the urinary catheter. The primary objective of this study was to compare the effect of sublingual and rectal misoprostol administrated before the cesarean section on hemoglobin level change due to intraoperative and postoperative blood loss. 
Table (1): Comparison between groups regarding baseline characteristics.

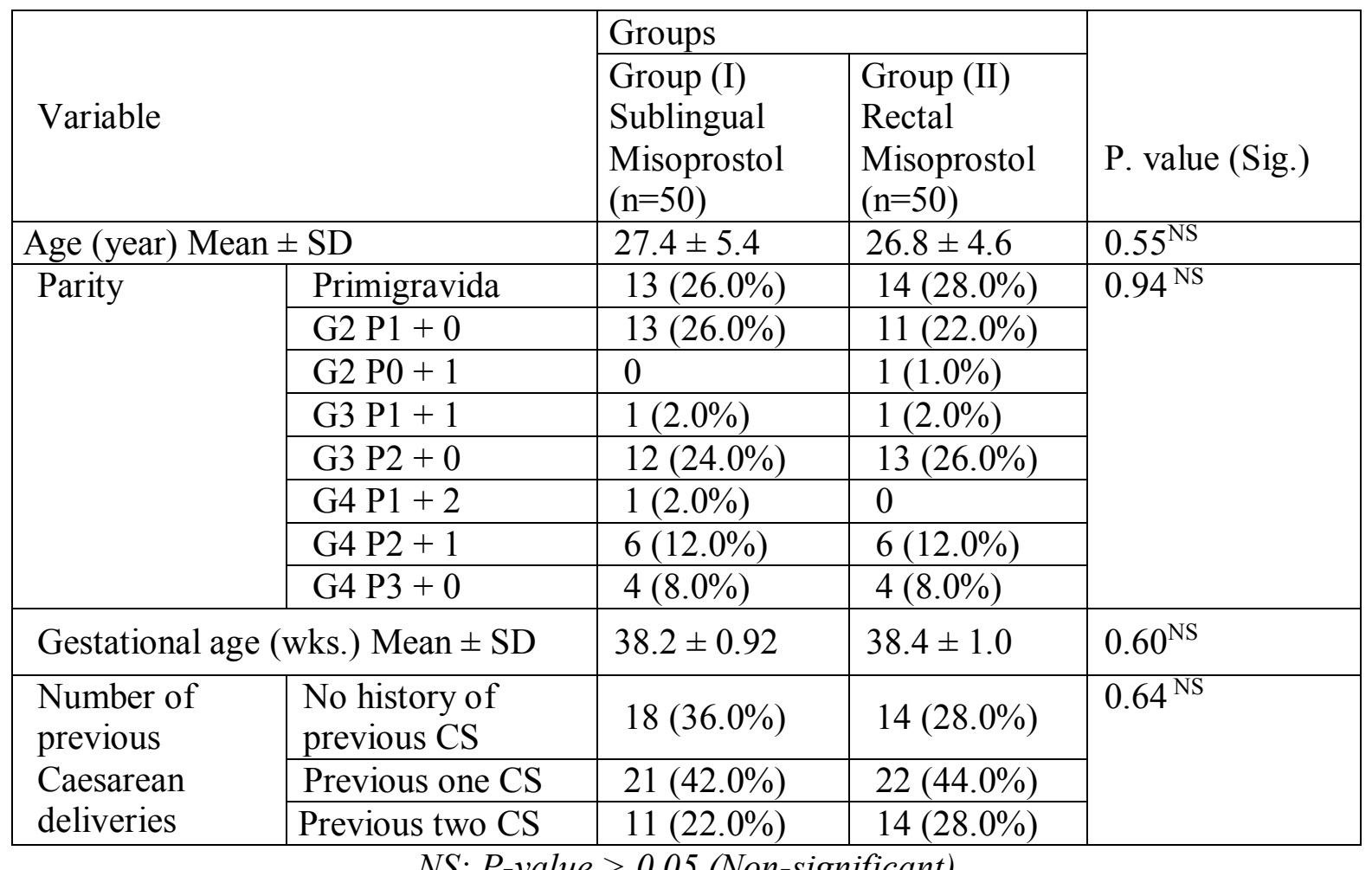

$$
\text { NS: P-value }>0.05 \text { (Non-significant) }
$$

Table (1) showed a comparison between groups regarding baseline characteristics. The results demonstrated that there were no significant differences between groups as regard age $(27.4 \pm 5.4$ year in group I vs. $26.8 \pm 4.6$ year in group II, $\mathrm{p}=0.55)$ (fig. 8 ), parity ( $\mathrm{p}=0.94)$, gestational age (38.2 \pm 0.92 wks. in group I vs. $38.4 \pm 1.0$ wks. in group II, $\mathrm{p}=0.60$ ) and number of previous caesarean delivery sections $(\mathrm{p}=0.64)$.

Table (2): Comparison between groups regarding intraoperative blood loss.

\begin{tabular}{|l|l|l|l|}
\hline \multirow{2}{*}{ Variable } & Groups & \\
\cline { 2 - 4 } & $\begin{array}{l}\text { Group (I) } \\
\text { Sublingual Misoprostol } \\
\text { M } \pm \text { SD }\end{array}$ & $\begin{array}{l}\text { Group (II) } \\
\text { Rectal } \\
\text { Misoprostol } \\
\text { M } \pm \text { SD }\end{array}$ & $\begin{array}{l}\text { P. } \\
\text { value } \\
\text { (Sig.) }\end{array}$ \\
\hline Blood loss (ml) & $456 \pm 187$ & $581 \pm 196$ & $<$ \\
$0.01 * *$
\end{tabular}

**Significant $(P<0.01)$.

Table (2) showed that women of rectal misoprostol group (group II) had a significantly higher amount of intraoperative blood loss compared to cases of sublingual misoprostol group (group I), (581 \pm 196 vs. $456 \pm 187 \mathrm{ml}$ in group II and I, respectively), $(\mathrm{P} \leq 0.01)$. 
Table (3): Comparison between groups regarding pre and post-operative $\mathrm{Hb}$.

\begin{tabular}{|l|l|l|l|}
\hline \multirow{2}{*}{ Variable } & \multicolumn{2}{|l|}{ Groups } & \\
\cline { 2 - 3 } & Group (I) & Group (II) & \\
& Sublingual & Rectal & Misoprostol \\
& Misoprostol & P. value \\
& $\mathrm{M} \pm \mathrm{SD}$ & $\mathrm{M} \pm \mathrm{SD}$ & (Sig.) \\
\hline Preoperative $\mathrm{Hb}(\mathrm{g} / \mathrm{dl})$ & $10.86 \pm 0.90$ & $10.92 \pm 0.92$ & $0.74^{\mathrm{NS}}$ \\
\hline Postoperative $\mathrm{Hb}(\mathrm{g} / \mathrm{dl})$ & $10.28 \pm 0.88$ & $10.14 \pm 0.67$ & $0.39^{\mathrm{NS}}$ \\
\hline P. value $($ Sig.) & $<0.01^{* *}$ & $<0.01^{* *}$ & - \\
\hline Percentage of $\mathrm{Hb}$ decrease & 5.34 & 7.14 & \\
\hline
\end{tabular}

NS: P-value $>0.05$ (Non-significant)

**Significant $(P<0.01)$.

Table (3) showed that no significant differences were found between groups regarding preoperative $\mathrm{Hb}$ level $(10.86 \pm 0.90 \mathrm{~g} / \mathrm{dl}$. in group I vs. $10.92 \pm 0.92 \mathrm{~g} / \mathrm{dl}$ in group II, $\mathrm{p}=0.74)$ and also postoperative $\mathrm{Hb}$ level $(10.28 \pm 0.88 \mathrm{~g} / \mathrm{dl}$. in group I vs. $10.14 \pm 0.67 \mathrm{~g} / \mathrm{dl}$ in group II, $\mathrm{p}=0.39)$. But, an obvious highly significant reduction was noticed in the postoperative $\mathrm{Hb}$ level in both groups $(\mathrm{P} \leq 0.01)$. The percentage of $\mathrm{Hb}$ decrease in rectal misoprostol group (group II) was higher than the sublingual misoprostol group (group I).

Table (4): Comparison between groups regarding pre and post-operative Hct.

\begin{tabular}{|l|l|l|l|}
\hline \multirow{2}{*}{ Variable } & \multicolumn{2}{|l|}{ Groups } & \multirow{2}{*}{} \\
\cline { 2 - 3 } & $\begin{array}{l}\text { Group (I) } \\
\text { Sublingual } \\
\text { Misoprostol } \\
\text { M } \pm \text { SD }\end{array}$ & $\begin{array}{l}\text { Group (II) } \\
\text { Rectal } \\
\text { Misoprostol } \\
\text { M } \pm \text { SD }\end{array}$ & $\begin{array}{l}\text { P. value } \\
\text { (Sig.) }\end{array}$ \\
\hline Preoperative Hct (\%) & $33.4 \pm 2.1$ & $33.7 \pm 1.9$ & $0.64^{\mathrm{NS}}$ \\
\hline Postoperative Hct (\%) & $32.1 \pm 2.1$ & $31.5 \pm 2.7$ & $0.21^{\mathrm{NS}}$ \\
\hline P. value (Sig.) & $<0.01^{* *}$ & $<0.01^{* *}$ & - \\
\hline Percentage of Hct decrease & 3.89 & 6.52 & \\
\hline
\end{tabular}

NS: P-value $>0.05$ (Non-significant)

**Significant $(P<0.01)$.

Table (4): showed the results of the comparison between groups regarding pre and post-operative Hct. At the same line of the results of $\mathrm{Hb}$, the results revealed that there were no significant differences between groups regarding preoperative Hct $(33.4 \pm 2.1 \%$ in group I vs. $33.7 \pm 1.9 \%$ in group II, $\mathrm{p}=0.64)$ and also postoperative Hct $(32.1 \pm 2.1 \%$ in group I vs. $31.5 \pm 2.7 \%$ in group II, $\mathrm{p}=0.21$ ). However, a highly significant reduction was found in postoperative Hct $\%$ in both groups $(\mathrm{P} \leq 0.01)$. Also, the percentage of Hct reduction was higher in the rectal misoprostol group (group II) compared to the sublingual misoprostol group (group I). 
Table (5): Comparison between groups regarding side effects and need for uterotonics.

\begin{tabular}{|c|c|c|c|}
\hline \multirow[b]{2}{*}{ Variable } & \multicolumn{2}{|c|}{ Groups } & \multirow[b]{2}{*}{$\begin{array}{l}\text { P. value } \\
\text { (Sig.) }\end{array}$} \\
\hline & $\begin{array}{c}\text { Group (I) } \\
\text { Sublingual Misoprostol } \\
(\mathrm{n}=50)\end{array}$ & $\begin{array}{l}\text { Group (II) } \\
\text { Rectal } \\
\text { Misoprostol } \\
(\mathrm{n}=50)\end{array}$ & \\
\hline Shivering & $46(92.0 \%)$ & $40(80.0 \%)$ & $0.09^{\mathrm{NS}}$ \\
\hline Nausea & $50(100.0 \%)$ & $50(100.0 \%)$ & $1.0^{\mathrm{NS}}$ \\
\hline Vomiting & $15(30.0 \%)$ & $6(12.0 \%)$ & $0.03 *$ \\
\hline Need for uterotonics & $3(6.0 \%)$ & $7(14.0 \%)$ & $0.18^{\mathrm{NS}}$ \\
\hline
\end{tabular}

Table (5) presented the comparison between groups regarding side effects and the need for uterotonics. Shivering and nausea were almost similar between groups with no significant difference. However, the incidence of vomiting was significantly higher in the group (I) compared to group (II) (15 cases vs. 6 cases). The results showed that 7 cases $(14.0 \%)$ in rectal misoprostol group needed uterotonics versus only 3 cases $(6.0 \%)$ in the sublingual misoprostol group, the difference between the group was not significant $(\mathrm{p}=0.18)$

\section{Discussion}

Cesarean delivery is the commonest major surgical procedure all over the world for females with a comparable incidence in both high and most low-income countries ranging from $20-30 \%$ worldwide [2]. PPH after CS is the commonest cause of maternal morbidity \&mortality, even in highly resourced countries and is continuously increasing in incidence [12]. Misoprostol is a synthetic analogue of PGE1 that acts as a uterine contractile agent. It is efficient in the prevention and treatment of $\mathrm{PPH}$ [13]. Sublingual misoprostol has the shortest onset of action, the highest peak concentration, and the greatest bioavailability among all routes of administration [14]. Rectally administered misoprostol is accompanied with slower absorption, lower peak levels, and decreased side effects in comparison with the oral \& sublingual routes [15]. The results of the present study revealed that there were no significant differences between groups as regard age $(p=0.55)$, parity $(p=0.94)$, gestational age $(\mathrm{p}=0.60)$, and the number of previous CSs $(p=0.64)$. This nonsignificant difference was important to ensure the homogenization of the studied groups to get accurate results from the comparison between groups. In this study, women of rectal misoprostol group (group II) had a significantly higher amount of intraoperative blood loss compared to cases of sublingual misoprostol group (group I), $(581 \pm$ 196 vs. $456 \pm 187$ in group II and I, 
respectively), $(\mathrm{P} \leq 0.01)$. These results are completely in agreement with another study [5]. that found the estimated blood loss in rectal misoprostol group was $457.5 \pm 140.7 \mathrm{~mL}$ compared to $357.8 \pm 129.7 \mathrm{~mL}$ in sublingual misoprostol group, they found that this difference between groups was significant $(\mathrm{P} \leq 0.01)$. In the current study, the difference between the rectal and sublingual groups in blood loss may be related to the rapid absorption and high bioavailability of misoprostol when given sublingually [16]. Sublingual misoprostol is known to reach the highest peak plasma concentration within the shortest time [5].

It has been reported that sublingual misoprostol observed to be more effective than the intravenous infusion of OXT in reducing blood loss during and after CS [17]. The rectal route of misoprostol had slow uptake, but the prolonged duration of action. The buccal and sublingual routes had a rapid intake, prolonged duration of action, and the greatest total bioavailability. It was concluded from the data reviewed that the most promising route of administration was the sublingual route [18].

In our study, no significant differences were found between groups regarding preoperative $\mathrm{Hb}$ level $(10.86 \pm 0.90 \mathrm{~g} / \mathrm{dl}$. in group I vs. $10.92 \pm 0.92 \mathrm{~g} / \mathrm{dl}$ in group II, $\mathrm{p}=0.74)$ and also postoperative $\mathrm{Hb}$ level $(10.28$ $\pm 0.88 \mathrm{~g} / \mathrm{dl}$. in group I vs. $10.14 \pm 0.67 \mathrm{~g} / \mathrm{dl}$ in group II, $\mathrm{p}=0.39$ ). However, an obvious, highly significant reduction was noticed in the postoperative $\mathrm{Hb}$ level in both groups $(\mathrm{P} \leq 0.01)$. The percentage of $\mathrm{Hb}$ decrease in rectal misoprostol group (group II) was higher than the sublingual misoprostol group (group I). These results agreed with a recent study [5], that study found that preoperative $\mathrm{Hb}$ was $10.7 \pm 1.0$ $\mathrm{g} / \mathrm{dl}$ in the sublingual misoprostol group in comparison with $10.5 \pm 1.0 \mathrm{~g} / \mathrm{dl}$ in the rectal group with no significant difference between groups. However, postoperative $\mathrm{Hb}$ was decreased to $10.3 \pm 1.0$ and $10.1 \pm 1.0 \mathrm{~g} / \mathrm{dl}$ in both sublingual and rectal misoprostol groups, respectively.

The difference between groups in postoperative $\mathrm{Hb}$ was not significant. However, the reduction in postoperative $\mathrm{Hb}$ was highly significant in both groups $(\mathrm{P} \leq 0.01)$. Also, they reported that the percentage of $\mathrm{Hb}$ decrease in rectal misoprostol group was higher than that of the sublingual misoprostol group. Also, our results are in harmony with another study [15] that compares the effect of sublingual versus rectal administrations of misoprostol on blood loss in cases undergoing an elective CS. They documented that preoperative $\mathrm{Hb}$ was $11.17 \pm$ 1.03 in the sublingual misoprostol group versus $11.32 \pm 0.97 \mathrm{~g} / \mathrm{dl}$ in the rectal misoprostol group $(\mathrm{P}=0.512)$. However, the mean postoperative $\mathrm{Hb}$ was higher in the sublingual group (10.00 \pm $1.13 \mathrm{~g} / \mathrm{dl}$ vs. $9.63 \pm 0.76 \mathrm{~g} / \mathrm{dl}, \mathrm{p}=0.463)$, it is 
obvious that the fall in $\mathrm{Hb}$ level was significantly higher in the rectal misoprostol group.

In our study, the same trend of results of $\mathrm{Hb}$ was found in Hct, the results demonstrated that there were no significant differences between groups regarding preoperative Hct $(33.4 \pm 2.1 \%$ in group I vs. $33.7 \pm 1.9 \%$ in group II, $\mathrm{p}=0.64$ ) and also postoperative Hct $(32.1 \pm 2.1 \%$ in group I vs. $31.5 \pm 2.7 \%$ in group II, $\mathrm{p}=0.21$ ).

However, a highly significant reduction was found in postoperative Hct \% in both groups $(\mathrm{P} \leq 0.01)$. Also, the percentage of Hct reduction was elevated in the rectal misoprostol group (group II) compared to the sublingual misoprostol group (group I).

Regarding the side effects of misoprostol, shivering, and nausea were almost similar between groups with no significant difference. However, the incidence of vomiting was significantly higher in the group (I) compared to the group (II) (15 cases vs. 6 cases). These findings corroborate with other studies $[15,19]$. As regards the need for additional uterotonics, the results showed that 7 cases $(14.0 \%)$ in rectal misoprostol group needed uterotonics versus only 3 cases $(6.0 \%)$ in sublingual misoprostol group, the difference between the group was not significant $(\mathrm{p}=0.18)$.

The need for additional uterotonic agents was less in the sublingual misoprostol group in our study, and this finding is similar to other studies [5, 20 and 21].

Finally, oral, buccal, rectal, and sublingual routes have been used in different studies. The sublingual route was chosen because it avoids oral intake, doesn't disrupt the operative field, and ensures continuous plasma levels of a potent uterotonic agent over a prolonged period. Pharmacokinetic studies on different routes of administration have shown that sublingual route achieved the highest serum peak concentration (C max), the shortest time to peak concentration ( $\mathrm{T}$ max), and the highest area under the curve (AUC) of misoprostol acid, the active metabolite of misoprostol [22, 23].

\section{Conclusion and Recommendations}

The sublingual route of administration of misoprostol is more effective in reducing intraoperative blood loss and postoperative $\mathrm{Hb}$ and Hct level decrease at CS than the rectal route but with no significant difference between groups postoperatively, and with more adverse effects in the sublingual group. Also, sublingual misoprostol reduces the need for additional uterotonics. Sublingual administration of misoprostol is recommended because it is favorable for patients and convenient of use than rectal one. Funding This Study did not receive any funds from any organization. 


\section{References}

1- Betran AP, Ye J, Moller AB, Zhang J, Gulmezoglu AM, et al. The Increasing Trend in Caesarean Section Rates: Global, Regional, and National Estimates: 19902014. PLoS One, 2016; 11(2): e0148343.

2- WHO (2015). World Health Organization (2015) WHO Statement on Caesarean Section Rates. World Health Organization, Geneva.

3- Fukami, $\mathrm{T}$, Koga $\mathrm{H}$, Goto $\mathrm{M}$, et al. Incidence and risk factors for postpartum hemorrhage among transvaginal deliveries at a tertiary perinatal medical facility in Japan. PLoS One, 2019; 14(1): e0208873.

4- Stood A, Kumar-Singh S. Sublingual misoprostol to reduce blood loss at caesarean. Journal of Obstetrics and Gynecology of India, 2012; 62(2): 162 167.

5- Nankaly A, Jalilian N, Eshghiali S, et al. The effects of sublingual misoprostol and intravenous oxytocin in reducing bleeding among cesarean deliveries. Acta Medica Mediterranea, 2016; 32: 953.

6- Sweed MS, El-Saied MM, Abou-Gamrah $\mathrm{AE}$, et al. Rectal vs. sublingual misoprostol before cesarean section: double-blind, threearm, randomized clinical trial. Archives of Gynecology and Obstetrics, 2018; 298:1115-22.
7- Omozuwa ES, Okonkwo CA. Randomized controlled trial of sublingual and rectal misoprostol administration on blood loss at elective caesarean section. European Journal of Biology and Medical Science Research, 2018; 7(1): 1-18.

8- Rajaei M, Karimi S, Shahboodaghi Z, Mahboobi H, Khorgoei T, Rajaei F. Safety and efficacy of misoprostol versus oxytocin for the prevention of postpartum hemorrhage. J Pregnancy, 2014; 20(14): 23-32.

9- Conde-Agudel A, Nieto A, Rosasbermudez A, et al. Postoperative hemorrhage during cesarean delivery: a systematic review and meta-analysis. Am J Obstet Gynecol. 2013; 209(1): 40.e1-40.e17.

10- Ayati S, Vahidroodsari F, Farshidi F, et al. Vaginal Versus Sublingual Misoprostol for Labor Induction at Term and Post Term: a Randomized Prospective Study. Iran J Pharm Res, 2014; 13(1): 299-304.

11-Lapaire O, Schneider MC, Stotz M, Surbek DV, Holzgreve W and Hoesli IM. Oral misoprostol vs. intravenous oxytocin in reducing blood loss after emergency cesarean delivery. Int $J$ Gynecol Obstet. 2006; 95:2-7.

12- Firmin, M, Carles G, Mence B, Madhusudan N, Faurous E, Jolivet A. Postpartum hemorrhage: incidence, risk factors, and 
causes in Western French Guiana. Journal of Gynecology Obstetrics and Human Reproduction, 2018; 15(1): e0238873.

13-Ugwu IA, Enabor OO, Adeyemi AB, Lawal OO, Olayemi O. Sublingual misoprostol to decrease blood loss after caesarean delivery: a randomised controlled trial. $J$ Obstet Gynaecol. 2014; 34(5): 407-11.

14-Khan RU, El-Refaey H. Pharmacokinetics and adverse effect profile of rectally administered misoprostol in the third stage of labor. Obstet Gynecol. 2003; 101: 96874.

15- Owonikoko KM, Arowojolu AO, Okunlola MA. Effect of sublingual misoprostol versus intravenous oxytocin on reducing blood loss at cesarean section in Nigeria: a randomized controlled trial. J Obstet Gynaecol Res. $2011 ; 37: 715-21$.

16- Tang OS, Schweer H, Seyberth HW, Lee SW, Ho PC. Pharmacokinetics of different routes of administration of misoprostol. Hum Reprod. 2002; 17:332-6.

17-Othman ER, Fayez Diaa MF, Abd El-Aal EM, Mohamed HS, Abbas AM, Ali MK. Sublingual misoprostol versus intravenous oxytocin in reducing bleeding during and after cesarean delivery: A randomized clinical trial. Taiwanese Journal of Obstetrics and Gynecology, 2016; 55(6): 791-5.
18- Hofmeyr GJ, Gülmezoglu AM, Novikova N, Linder V, Ferreira S, Piaggio G. Misoprostol to prevent and treat postpartum haemorrhage: a systematic review and metaanalysis of maternal deaths and dose-related effects. Bull World Health Organ, 2009; 87: 666-77.

19-Vimala N, Mittal S, Kumar S. Sublingual misoprostol versus oxytocin infusion to reduce blood loss at caesarean section. Int $J$. Gynaecol Obstet. 2006; 92(2): 106-10.

20-Yehia A, Wafa MD, Fahad A. El-Omda MD, Mohamed E, Hammour MD, Elkeleeny SM. Effect of Sublingual Misoprostol on Blood Loss during and after Cesarean Section. Med. J. Cairo Univ. 2017; 85(5): 1999-2007.

21-Hamm J, Russell Z, Botha T, et al. Buccal misoprostol to prevent hemorrhage at cesarean delivery: A randomized study. Am.

J. Obstet. Gynecol. 2005; 192: 1404- 6.

22-Schaff EA, DiCenzo R, Fielding SL. Comparison of misoprostol plasma concentrations following buccal and sublingual administration. Contraception, 2005; 71(1): 22-25.

23-Tang OS, Gemzell-danielsson K, Ho PC. Misoprostol: Pharmacokinetic profiles, effects on the uterus and side-effects. Int. $J$. Gynaecol. Obstet. 2007; 99: S160-S167. 